
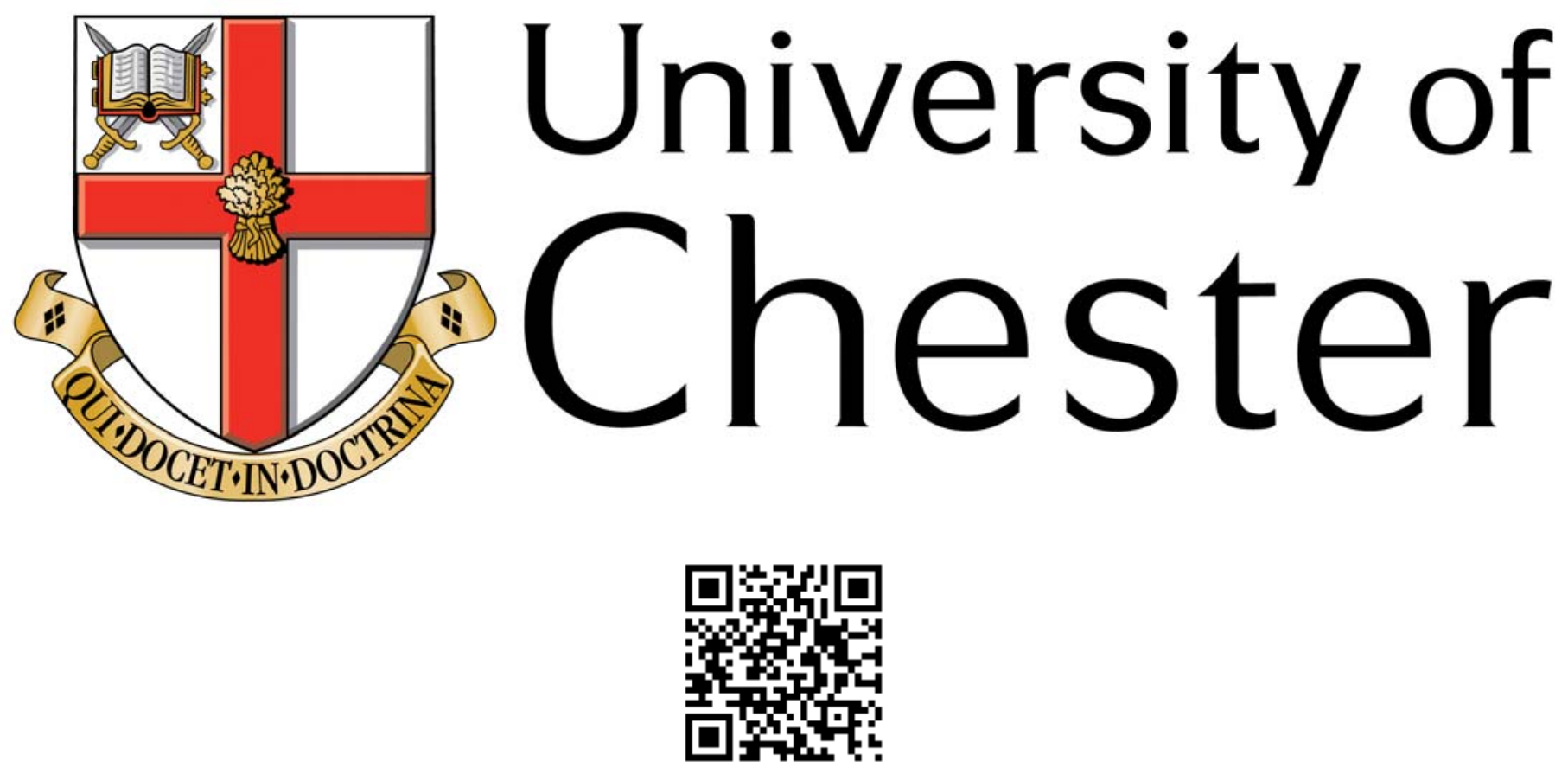

This work has been submitted to ChesterRep - the University of Chester's online research repository

\title{
http://chesterrep.openrepository.com
}

Author(s): Elizabeth Harlow ; Elizabeth Berg ; Jim Barry ; John Chandler

Title: Neoliberalism, managerialism and the reconfiguring of social work in Sweden and the United Kingdom

Date: 2013

Originally published in: Organization

Example citation: Harlow, E., Berg, E., Barry, J., \& Chandler, J. (2013).

Neoliberalism, managerialism and the reconfiguring of social work in Sweden and the United Kingdom. Organization, 20, 534-550. http://dx.doi.org/

$10.1177 / 1350508412448222$

Version of item: Author's accepted version 


\section{Neoliberalism, Managerialism and the Reconfiguring of Social Work in Sweden and the United Kingdom ${ }^{1}$}

\section{Abstract}

This paper considers some of the ways in which neoliberalism, through the processes of managerialism, has impacted on the occupation of social work in Sweden and the UK. It is argued that there are similar implications in both countries, through the managerial drive for increased performance in economy, efficiency and effectiveness, but also in the development of evidence based practice. Whilst the key focus of the paper is on similarities between these two countries, differences are also noted. There is also recognition of the way in which resistance to the reconfiguration of social work is taking shape.

\section{Key words}

Social work, social work reconfiguration, social work occupation, social work profession, deprofessionalization, neo-liberalism, managerialism, Sweden, United Kingdom.

\section{Introduction}

This paper explores neoliberalism, managerialism and the organization and construction of social work in Sweden and the United Kingdom (UK). Although local discourses concerning citizenship and the provision of welfare create differences, social work exists as an organized

\footnotetext{
${ }^{1}$ Whilst this paper refers to the United Kingdom, in some instances Scotland and Northern Ireland have their own legislation and policies. 
occupation in all continents of the world (Barnes and Hugman, 2002). According to the International Federation of Social Work, social work:

promotes social change, problem solving in human relations and the empowerment and liberation of people to enhance well-being. Utilising theories of human behaviours and social systems, social work intervenes at the points where people interact with their environments. Principles of human rights and social justice are fundamental to social work (www.ifsw.org/f38000138/html accessed 18/11/10).

Commonalities in what is understood as 'social work' in both Sweden and the UK, might stem, to some extent, from shared intellectual and theoretical underpinnings. For example, training courses in both Sweden and the UK draw on the same literature, such as Payne's (2005) book Modern Social Work Theory (Svensson et al., 2008). But the precise boundaries of 'social work' in the two countries may differ: those engaged in social care work in Sweden may be considered social workers, though not so in the UK, whilst practice with children, families and some vulnerable adults may be similar in both countries. However, we do not wish to engage in definitional arguments. We simply wish to explore how neoliberalism and managerialism might be contributing to its reorganization and reconstruction, if at all.

Gaining credibility as an occupation or 'new profession' during the post war development of the welfare state, social work may constitute a relevant and interesting case study: that is, social work is a construction of a bureau-professional regime (Clarke and Newman 1993) that emerged at a particular point in history. As change and development continues, then this is likely to be reflected in its on-going reconstruction. Studying this one occupation is an exploration of how neoliberalism is becoming organizationally and occupationally embedded 
in the provision of welfare: social work is discussed here as an exemplar of wider social trends. Furthermore, we do not intend systematically to contrast the present state of social work with that of the past; rather we want to focus on comparing the two countries. In doing this we do not judge the present against a romanticized view of the social work of yesteryear. We are conscious that in the period following 1945, the welfare state's 'supporters ... [were] among its strongest critics' (Wilding, 1986: 2; see also Wahlberg, 2001; and Svensson et al., 2008).

In choosing Sweden and the UK we have, moreover, chosen countries that might be expected to reveal differences in this manifestation. Sweden is a country with a strong social democratic tradition, which can be seen as offering a rather hostile environment for the incursion of neoliberalism, while the UK is often seen, along with the United States, as at the forefront of neoliberal reform. In focusing on social work in two countries, we avoid some of the problems associated with the comparison of 'welfare regimes' in general. Kasza (2002), for example, sees the comparison of welfare regimes as dubious. This is because the complexity of social policy making results in each country's internal difference, such that the concept of 'regime' becomes problematic. Even though we do draw on the idea of regime, we follow Kasza's suggestion of giving attention to policy-specific areas: it is suggested that this is a more promising avenue for a comparative project. This also enables us to explore neoliberalism as an ideological or discursive influence that is variegated, rather than being representative of 'one hegemonic form of capitalism' (Birch and Mykhnenko, 2009: 355). In examining one occupation in two countries we might be expected to shed some light on the extent and nature of such variation. 
In writing this paper in 2011, at a time when economic crisis and political change in the United States of America and Europe might just mark a turning point for neoliberalism, there is a danger that a consideration of neoliberalism will come to be seen as of merely historical interest. Yet it is precisely in such circumstances that a clear understanding of the neoliberal influence becomes most important. As the possibilities for change open up, we need to understand what it is we want to leave behind, and what it is we want to take forward. In what follows, our intention is not, however, to make a contribution to the debate on the periodisation or phasing of neoliberalism (see Craig and Cotterell, 2007): instead, it is to explore the neoliberalism and the construction of social work, recognising that authors such as Clarke (2004b) have implicated managerialism in this process.

In analyzing neoliberalism, managerialism and social work the paper draws on changing legislation, policy developments and government reviews in both Sweden and the UK. Critical comment, empirical and theoretical contributions of academics (for example, Garrett, 2008; Jones, 2001; Kelly, 1991; Lawler, 2000; Postle, 2001 and Powell, 2001) are also taken into account. This paper is therefore not the result of an empirical research project, but a theoretical exploration of developments in social work that have been underway since the 1970s. The claim that neoliberalism and managerialism are reconstructing social work is not itself new (see for example, Harlow, 2003 and Harris, 2003), but the attention to resistance and the cross-cultural examination of social work in Sweden and the UK is original: it is by taking this different approach that we hope to add to the current body of literature and contribute to the ongoing development and exchange of ideas.

The disciplinary backgrounds and different nationality of the authors has provided the opportunity for this project, but the exploration was inspired by the desire to understand what 4 
appears to be a reconfiguration of social work: an accumulation of changes that have been taking place over the last thirty years. We asked a series of questions such as: "what influences have given rise to the changes we have witnessed professionally and personally? Are these influences impacting on social work in both Sweden and the UK?' Initially, managerialism was the focus of attention, but on closer scrutiny it was concluded that managerialism may be a means of making material the ideology or discourse of neoliberalism.

In the next section we focus specifically on the changing post-war contexts of neoliberalism and managerialism and the implications for the public realms of the countries in question. We then go on to examine social work in terms of these reconfiguring pressures in both countries. Following a reflection on the way in which the identified trends are being resisted, we summarize our thoughts. This final summary is not intended to act as a 'conclusion', but as a contribution to an on-going discussion.

Changing Contexts and Public Realms: neo-liberalism and managerialism

In most of the post-second world war period, the settled worlds of welfare for Sweden and the UK were identified by Esping-Anderson (1990) as social democratic and liberal welfare regimes respectively. Whilst, to a degree, these may have been imagined worlds, their intellectual utility has held considerable sway in the academic community. More recently, however, a new ideological or discursive influence has been discerned as extending its reach far and wide, even if its present and likely future impact is unclear: neoliberalism. 
Neoliberalism probably dates, according to Harvey (2005), from 1978-80. A series of events in different parts of the world, including the election of politically right-wing Reagan and Thatcher governments in the US and UK respectively, indicated a turning point in world affairs. Harvey's comments on what is meant by neoliberalism are worth quoting at some length:

\begin{abstract}
Neoliberalism is in the first instance a theory of political economic practices that proposes that human well-being can best be advanced by liberating individual entrepreneurial freedoms and skills within an institutional framework characterized by strong private property rights, free markets, and free trade. The role of the state is to create and preserve an institutional framework appropriate to such practices ... There has everywhere been an emphatic turn towards neoliberalism in political-economic practices and thinking since the $1970 \mathrm{~s}$... Neoliberalism has, in short, become hegemonic as a mode of discourse. It has pervasive effects on ways of thought to the point where it has become incorporated into the common-sense way many of us interpret, live in, and understand the world (Harvey, 2005: 2 - 3).
\end{abstract}

Whilst acknowledging that not all states have actually succumbed, Harvey nonetheless points to a pervasive influence that affects thinking and practice, to the degree that it has become normalised, with 'individual freedoms ... guaranteed by freedom of the market and of trade' (Harvey, 2005:7). His linking of politics and economics is no accident, for neoliberalism drew and gained inspiration not just from a classical liberalism that had flourished in the nineteenth century writings of Bentham and Mill, but also the embedded liberalism of Keynesianism that had gained ground a century later only to falter, following the relatively short-lived post war boom, towards the end of the 1960s (Harvey, 2005). The influence of 6 
economists such as Hayek (1944 and 1966) and Friedman (1962), is, however, a pervasive one since it was the special blend of their economics with right wing politics that gave neoliberalism its dynamic character. This is particularly so when compared to traditional onenation, right-wing conservatism that found itself effectively sidelined under the US and UK regimes of Reagan and Thatcher. It also served to straightjacket erstwhile socialist parties which subsequently found that they were incorporating neoliberal thinking in a post-political middle ground that mirrored the Butskellite consensus of the post-war years. Indeed, so influential did these ideas appear to become, that Fukuyama (1989) proclaimed the end to history: in this new era, conflicts of social class, religious fundamentalism and nationalism would constitute relics of a not-so-golden age that had passed, even if shifts in world affairs have since suggested otherwise.

However, we are conscious that there are many ways of conceptualising neoliberalism. The phenomenon has been much debated, especially among critical human geographers, whose varying approaches have conceptualized neoliberalism as 'a policy paradigm; sometimes more broadly as a hegemonic ideology; and sometimes as a distinctive form of governmentality (Larner, 2000)' (Barnett, 2009:270). Whilst all of these conceptualizations have value, for the purposes of this paper, neo-liberalism is understood as an ideology or a discourse. Furthermore, we are persuaded by theorists such as Lewis (2009), who rejects totalizing interpretations of neoliberalism and calls for more nuanced accounts.

We are following the lead of Clarke (2004a), for example, who highlights variation in the manifestation of neoliberalism and reminds us of the possibilities for 'contradiction and 
contestations' as well as 'forms of refusal, resistance and accommodation' (Clarke, 2004a: 30). In the 'dispersed state' of reconfigured organisational forms and agencies (Clarke, 2004b: 116; Clarke and Newman, 1997), much is open to negotiation. This negotiation occurs between politicians, professionals, users, new public managers and agents, suggesting, at least potentially, considerable variation in implementation. Moreover, with reference to public opinion in the UK, Clarke points to:

... a surprising degree of continuity throughout this [recent] period of neo-liberal dominance, [with the public] tending to see 'more resources' rather than 'better management' as the key to improving public services (particularly in health and education); and viewing responsibility for service provision (and service failures) as located with government, rather than 'local management' (Clarke, 2004a: 38).

Yet despite this lively critical engagement, we think it is important to recognize that, whatever the complications, the sense of forward movement of neoliberalism remains. Whilst Leys (2001: 1), for example, contends that 'politics everywhere are now marketdriven' (italics in original), a recent popular history of modern Britain somewhat pithily sums up the story as the 'defeat of politics by shopping' (Marr, 2007: ix). Although the focus of both these writers is on aspects of the public realm in Britain, Leys argues that the lessons, for other countries including Sweden, should not be ignored (Leys, 2001).

Neo-liberal ideas are materialized or implemented through what Clarke calls the 'organizational glue' of managerialism. It has been argued that managerialism has been used to spearhead a 'permanent revolution' in the public sphere. In this, '[m]anagerialism has been 
the dominant organizational strategy (and discourse) for coordinating public services - and "performance" is a particular development within this framing of organizational control' (Clarke, 2004b: 128-129). Moreover, pressures to reorient collective professional loyalty in favour of individual organisational commitment reinforce these processes through the 'one best way' prescriptions of the new public management. These have been operationalized in the pursuit of fiscal austerity, transparency and public legitimacy, in different contexts, to embed techniques of scrutiny such as audit and performance management, as well as evidence based policy and practice (Clarke, 2004b). This focus on performance facilitates the exercise of management from a distance, essential for the dispersed state; but there are implications. One of these is that this process involves 'tak[ing] "politics" out of policy', thereby elevating a seemingly neutral technicism.

Whilst managerialism may offer the 'apolitical' techniques through which the neoliberal agenda could be pursued, this interpretation might be too narrow (Lawler, 2000). Drawing on the work of Clarke et al. (1994) Lawler argues that managerialism itself has transformative potential: managerialism is transforming relationships of power, culture, control and accountability. However, it is important to note that the outcome of managerialism is uncertain. Management itself is a human process that is open at the very least to mediation and modification, if not outright subversion. Managerialism, like neoliberalism (as noted above) is unlikely to lead to a given consequence. Both managerialism and neoliberalism may champion the idea of economy, efficiency and effectiveness in the provision of social care, and in doing so promote marketization and performance measurement, but the outcomes cannot be predicted. Furthermore, for Clarke (2004b), neo-liberalism, along with the new public management, is 'enacted in different hybridised formations - in different national 
politics, in different regional contexts' (Clarke, 2004a: 44). The task, therefore, is not to assume its dominance but to explore attempts to resist its influence. As Craig and Cotterell contend:

... examining particular areas of policy and events, we begin to see the complexity of change and continuity ... [that] ... allows us heuristically to 'crack' the otherwise monolithic facade of the neoliberal project. In terms of activism, it lets us begin to see areas in which it may be being challenged (Craig and Cotterell (2007: 510).

The ideas presented in this section, then, suggest that while neoliberalism might be influential, it might also take a number of different forms; while it might be a powerful discourse it might be contested. Moreover, Clarke (2004b) provides powerful arguments for linking managerialism and neoliberalism, with the former providing the means by which the latter can be implemented while also providing an apolitical mask to disguise the intensely political nature of reform. In the remaining sections we want to examine how the ideologies/discourses as identified above might contribute to the configuration and reconfiguration of social work in Sweden and the UK. We do so without assuming the triumph of neoliberal managerialism or complete resistance and contestation. Furthermore, we do so expecting to observe sameness as well as difference between the two countries. 


\section{The Progression of Neo-liberalism and Organizational Reconfiguration}

Sweden, with its social democratic history is associated with a 'Scandinavian' model of high taxation and high welfare standards (Esping-Anderson, 1990). Within this tradition, principles of equity and inclusiveness contribute to a culture of solidarism (Hirst, 1998). This

can be seen as part of a post second world war settlement. Apart from a brief period of Conservative-led coalition government in the early 1990s, the Social Democratic party was the dominant force in government until 2006 when a new right-wing coalition came to power (see Hirst, 1998 and Pollitt and Bouckaert, 2004). This party was re-elected in 2010 and formed a minority government. Not surprisingly, therefore, social policy in Sweden can be seen as having experienced a degree of stability, based on popular support. In addition to high standards of welfare, a central component of Swedish social policy has been 'arbetslinjen' (which roughly translated means the working line). Arbetslinjen emphasizes the importance of unemployed people gaining work. Gaining employment is facilitated by education or by relocation to areas where jobs are available (Olofsson, 2009).

As economic problems mounted in the 1980 s a political-ideological discussion started to challenge the traditional Swedish welfare model (Oscarsson, 2000) and the existing arrangements came into question. However, it was not until the mid 1990s that new public management took hold (Pollitt and Bouckaert, 2004), with greater emphasis being placed on performance management, efficiency, accountability and decentralisation (Holmberg and Henning, 2003; Larrson, 2002 and Christensen and Lægreid, 2007). In the workplace this was associated with an increase in the delegation of accountability, surveillance, work intensification and financial restrictions (Holmberg and Henning, 2003). 
In the post-war era social work in Sweden has taken place largely within local authorities and Health County Councils that have responsibility for health and education as well as social care, and this has provided a largely stable and, until recently, expanding organizational space for the development of social work. However, private provision of health and social care did continue through the post-war period (Meeuwisse et al., 2006), with opportunities for private companies to provide social work increasing from the early 1990s (Berg, 2003). This led to a greater spread of social workers across organizations in the public, private and 'third' sectors and greater differentiation within the occupation.

The UK, which has evolved within the context of a liberal welfare regime (Esping-Anderson 1990), adopted neoliberal ideas with enthusiasm. This began to occur most explicitly with the election of the Conservative government in the late 1970s - a political environment favourable for the reform and reorganization of public services (Ackroyd et al 2007). This was so not only under Margaret Thatcher, whose governments were most obviously associated with the neoliberal project, but also under Labour governments. Even after the defeat of the Conservatives in 1997 there was a continued commitment to both marketization and managerialism. There has been limited enthusiasm for rolling back the most significant neoliberal reforms in the areas of trade union legislation, or the use of private and 'third' sectors to provide public services. Thus, despite the rhetoric of the Labour government's 'third way' and some marked differences on social policy in the area of 'social investment' in the NHS and education, neoliberal assumptions continued to have influence (see Garrett, 2008, 2009). 
As in Sweden, the state in the UK did not have a monopoly on the provision of social care (Siddall, 2000). However, the principles of neoliberalism have given rise to legislation and policy initiatives that encourage the privatization of services, the introduction of internal markets, and the requirement for local authorities to use competitive tendering as a route towards outsourcing the provision of services. For example, residential or foster care for children, as well as residential care and domiciliary services for adults, may be provided by independent agencies in the private and not-for-profit 'third sector' rather than the state (for example, see Sellick, 2007). With the dismantling of Social Services Departments (which were first established in 1971) field social workers are now located in the multi-disciplinary contexts of Care Trusts, Children's Trusts or Education Departments. More recently, the government has advocated the introduction of 'social work practices' - small organizational partnerships between child care social workers, and members of the third and private sector, that would work under contract to the local authority (Department for Children Schools and Families, 2008).

It would appear that global economic challenges in the latter quarter of the last century contributed to political and policy change in both Sweden and the UK. Despite variation in implementation, both countries embraced neoliberal thinking. To a greater or lesser extent, both countries subordinated politics to a particular kind of economics. In both countries the cost of welfare came into question. Structural reorganization occurred and there was an increase in the practice of contracting services from the private and voluntary sector. Private sector managerialism came to be seen as a means of making the most of public investment: that is, managerialism became the mechanism by which public services, such as 13 
social work, could become more economic, efficient and effective (Hinnfor, 2006; Kelly, 1991). Finally, the reconfiguration of professional knowledge and expertise became significant mechanisms through which governments began reshaping social work in both countries (see below).

\section{Neoliberalism, Managerialism and the Reshaping of Social Work}

In the UK, commentators have drawn attention to the consequences of the welfare reforms as involving the re-shaping of social work practice. This reshaping involves: the fragmentation of social work; deprofessionalization; the increased technicism and managerialization of the role; and the loss of professional autonomy. Fragmentation has occurred in at least two different ways: firstly, generic social work has been undermined as work with adult offenders has been removed to a specialist area requiring a different qualification based on its own knowledge and practice competence (Harris, 2003; James, 2004). Secondly, fragmentation has also occurred in relation to day-to-day tasks: specialist teams are responsible for initial contact, assessment, and intervention or service provision:

Reminiscent of Ford's production line, this approach can be understood as 'conveyer belt care' in that, once tasks have been completed, individuals and families are passed from one specialist team to another until their cases are closed (Harlow, 2003: 35).

The deprofessionalization of social work has occurred in that its claims to a specialist body of knowledge have been eroded. For example, work with adults experiencing mental ill-health can now be undertaken by 'mental health professionals', many of whom have been trained within the discipline of health rather than social work. Similarly, work with elderly people or 14 
adults with physical disabilities may be undertaken by care managers who are no longer required to have a social work qualification: for example, they may be trained and qualified as occupational therapists. Finally, the children's workforce (for example, nursery nurses, teachers and social workers) are all expected to have a common knowledge base and 'skill set' (Department for Education and Skills, 2005a) and be equipped to assess the needs of children according to a common framework (Department for Education and Skills, 2005b). It might be argued that professional boundaries become blurred as tasks previously the remit of social workers only, might now be undertaken by those with different qualifications. This trend is intended to streamline the provision of services and encourage the development of a more flexible workforce (Garrett, 2008). The set of roles that remain most clearly within the remit of qualified social workers are those concerning child protection and corporate parenting.

The role of the social worker has itself become increasingly technicist and managerial with practitioners assessing need and then coordinating the work of others as opposed to engaging in direct work with service users. This shift has occurred in all areas of social work, in both Sweden and the UK, but is seen most readily in work with vulnerable adults, where budgetary responsibility is also implicated (see for instance Berg 2008). In the UK, the changed role title from social worker to care manager reflects this shift as articulated in this practitioner's comment:

Being a care manager is very different from being a social worker as I had always thought of it. Care management is all about budgets and paperwork and the financial implications for the authority, whereas social work is about people. That's the crucial difference (Care manager quoted by Jones, 2001: 553). 
The changed role of the social worker from relationship-based engagement with service users to the assessment of need, and the co-ordination of services delivered by others, has been described as the 'management technicist perspective' (Harlow, 2003: 34) or the 'rationaltechnical approach' (Ferguson, 2011). This shift has been identified as problematic when the care and protection of children is at issue. According to Munro:

The professional account of social work practice 'in which relationships play a central role' appears to have been gradually stifled and replaced by a managerialist account that is fundamentally different. The managerialist approach has been called a 'rational-technical' approach where the emphasis has been on the conscious, cognitive elements of the task of working with children and families, on collecting information and making $\mathrm{pl}$ ans. This focus has led to a 'a curious absence from a great deal of social work and child protection literature, policy and discussion about practice of any considered attention to the core dynamics, experience and methods of doing the work' (Munro, 2011: 86 drawing on the work of Ferguson, 2011).

Munro goes on to say:

The responses collected by Community Care and the British Association of Social Workers (BASW) to the review's questions about practice echoed a picture of a managerial focus on process rather than practice, with reduced time for providing help to children and families themselves so that, after assessment, children and families are generally referred to other services (Munro, 2011: 87). 
In terms of practitioner autonomy, practitioners of the past enjoyed a relatively high degree of freedom to analyze the circumstances of the service user, choose their preferred method of working and organize their time accordingly (Harris, 1998). This was supported by a system of supervision that saw senior social workers (or team leaders) facilitating practitioners in their reflection and decision-making. Since the 1980s this system has been eroded and senior social workers have been replaced by managers who audit performance in keeping with the parameters of satisfactory output (Harris, 1998).

In summary, this reshaping of social work within the UK not only concerns knowledge, skill and areas of responsibility and expertise, but also the increased importance of managerialism. In-keeping with the neoliberal emphasis on cost reduction, there has been a rise of a Taylorist approach to social work practice: with practice itself becoming technicist and managerialist (Harlow, 2003). The worker's role has been reduced to specific tasks whilst contact with service users is brief, centrally directed and micromanaged. With reduced emphasis on direct practice, as well as reduced autonomy (Harris, 2003), this reconstruction of social work and increased mangerialism has led to widespread dissatisfaction. According to Brand (2009), social workers being unable to stand up to this regime:

...have sacrificed their professional skills on the altar of the Management God and in the last analysis this surrender serves them ill; their professional self-esteem has been destroyed and their job satisfaction has disappeared (Brand, 2009: 11). 
In consequence, many practitioners have become dissatisfied and resigned from their posts (Carey, 2009; Harlow, 2004). At the same time, recruiting new practitioners has posed a problem with the government responding with recruitment drives and the provision of student bursaries. The on-going difficulties in the staffing of social work services, has created a business opportunity for private employment agencies that pay higher salaries and provide social workers to local authorities on temporary contracts. Thus in 20056,925 (full time equivalent) social workers working on long term temporary contracts for local authorities were employed by private agencies (Local Authority Workforce Intelligence Group, 2006) ${ }^{2}$.

As new public management, acting as a set of principles and approaches to relationships and practices, came to be implemented in Sweden in the 1990s, changes in state benefits also occurred, changing the relationship between clients and welfare agencies (Åström, 2000). For example, the conditions for unemployed people and people on sick-leave from paid employment have been changed and indicate a desire to cut back state welfare provision. In the same decade, Sweden also saw the growth of marketization and an increased role for the private sector service provision. This was partly because, within the context of changing legislation, private entrepreneurs could generate income by subcontracting service responsibilities from local authorities (Holmberg and Henning, 2003; Svensson et al., 2008). Outsourced social services included cleaning and food delivery. These new arrangements demonstrated that users were not entirely dependent on public sector Social Welfare Departments (Holmberg and Henning, 2003). In addition, these alternative arrangements

\footnotetext{
${ }^{2}$ It is interesting to note that some practitioners may prefer to be employed by an agency rather than by the local authority. Whilst higher salaries (though fewer benefits) may contribute to this, the topic is complex and a full discussion lies beyond the remit of this paper.
} 
encouraged the recipients of services to be reconstructed as consumers (see below). Importantly, these developments can be appreciated as attempts to improve the quality of services which had previously been provided at a minimal level. Such developments, however, contributed to the changed role of social workers, who in earlier configurations, (those of the 1970's for example) often held the radical aim of changing society and thereby preventing social problems. Put another way, in the 1970's and early 1980's, social workers were frequently seen as professionals and visionaries rather than managers responsible for facilitating the consumption of services (Svensson et al 2008; Wahlberg 2001).

As indicated above, new public management, or managerialism, is associated with the idea of consumption. Uniform services have been criticised and solutions framed in terms of consumer-based citizenship and choice. In the UK, the diversification of service providers by market mechanism has been legally required, and social work 'clients' have become 'service users' (for a fulsome discussion of changed nomenclature see McLaughlin, 2009) who, in principle at least, exercise their right to choose:

The marketisation of relationships in health and welfare promotes efficiency among providers by subjecting them to bracing competition, and increased choice for users who are expected to exercise responsible and rational discretion on their own behalf. The assumption is that needs are transparent and obvious to the consumer, requiring no interpretation by professionals, and that welfare is merely a commodity (Froggett, 2002: 70). 
Reconceptualizing clients as service users is similar in the UK and Sweden. For example, in Sweden, supported by legislation, service users now have the right to employ personal assistants, financially supported by the Social Welfare Department. The individual has also been granted a reinforced right to argue their case against authority decisions (Åström, 2000). Service users and their families must take responsibility for identifying social needs and solutions, and must also cooperate with social workers and other professionals to these ends (Berg, 2008). By means of this new policy, users must be active rather than passive (Berg, 2008). This is in line with neoliberal principles that encourage individualized responsibilities and duties. In consequence, the shift from client to user may reflect demands from users, but it is also related to a top down perspective, as public sector authorities define social problems and the way in which they should be treated (Svensson et al., 2008).

\section{Performing Management}

Another similarity between Sweden and the UK has been a drive for social work practice to be explicit and overtly based on evidence. This is an important element of the ideology or discourse of managerialism that falls within the orbit of what has been termed 'performativity'. As Dent and Whitehead (2002) explain:

... for professional status to be legitimized, it has to be based on 'scientific' knowledge. In other words the professional must succumb to the pressure to be measured against so-called 'objective' criteria in scientific mode ... The professional's account is no longer sufficient of itself and must be measured and 
inspected against external criteria or targets of performance, all of which purport to be 'scientific' and thus accurate and dispassionate, not open to question or doubt as models of 'truth' (Dent and Whitehead, 2002: 8).

Performance management includes audit inspection, evaluation, regulation and 'evidence based policy and practice' (Clarke, 2004b: 131). The idea of evidence-based practice (EBP) has been attributed to Sackett et al. (1997) who, in the field of medicine, argued for ' [...] the conscientious, explicit, and judicious use of current best evidence in making decisions about the care of individual patients' (Sackett et al., 1997: 2). As a supposedly 'rational' method of ensuring control over how work is performed, EBP is clearly consistent with, and increasingly part of, a managerialist agenda in Swedish and UK public sectors.

The advocates of EBP argue that it will improve the quality of services as well as make the decisions and methods of social work transparent to all, including service users (and managers, of course). In consequence, the Swedish government is stressing the importance of social workers using and supporting this new approach and ensuring that the principles are promoted within the education of practitioners (SOU, 2008). In keeping with the approach in Sweden, the UK government established the Social Care Institute of Excellence (SCIE) in 2001 as the 'key source of evidence-based policy' (Fisher, 2002: 8). There has also been a rise of research dissemination projects such as Research in Practice (ww.rip.org.uk), its younger sister Research in Practice for Adults (www.ripfa.org.uk), and Making Research Count. 
However, in both countries the increased call for evidence based practice (EBP) has given rise to questions concerning the construction of social work and its epistemological underpinnings. Objections to the rise of EBP come from a number of sources: firstly there are those arguing that social work does not require a specialist knowledge base and that the kind of problems with which social workers deal are 'general' rather than specialist and therefore solutions are already available to lay people (Rosen, 2003). Secondly, according to some, the foundations of social work knowledge lie within art rather than science (see England, 1986). For such critics the application of positivist principles to the generation of social work knowledge is alien to a practice that is socially constructed. This leads to a further objection, namely that the proponents of EBP fail to engage with the political aspects of the construction of social work:

Not only are we being led to a narrowly constructed notion of welfare, but also to a similarly constrained notion of what constitutes knowledge. A kind of crosscontamination has occurred whereby the scientism of the one reinforces the depoliticisation of the other (Butler and Pugh, 2004: 63).

The impulse to performativity from managerialism in both Sweden and the UK thereby legitimates EBP as it depoliticizes its introduction, enabling the enactment of a neo-liberal agenda of individualized target-setting and control across varying organizational contexts.

New Possibilities and Resisting the Neoliberal Reconfiguration? 
Although the ideology or discourse of neo-liberalism appears to be progressing and reconfiguring welfare in general and social work in particular, its manifestation and the response it engenders is uncertain and mixed. For example, the reorganization of welfare services does not always lead to greater economy or poorer services. According to Sellick (2007), who has researched the new mixed economy of foster care for children in the UK, these new arrangements have led to improvements for foster carers, but also increased cost. Similarly Jordan with Jordan (2000), suggest that some community-based initiatives that have emerged over recent times, have been exciting and full of potential, even if social workers have not had a key role. New conceptualizations and organizational change lead to altered occupational opportunities. So, while in adult services some lament the shift from social work practitioner to care manager, others see the development of new possibilities (Berg et al., 2008). Furthermore, the emphasis on EBP means that investment in knowledge generation and dissemination is taking place, even though the investment may be at a relatively low level, and the knowledge is of a specific kind.

Despite some tendencies to the marginalisation of social work, its status as a distinct occupational entity has in some ways been strengthened in the UK: the term 'social worker' has become a 'protected title' (General Social Care Council, 2008), requiring degree level formal training and registration with the General Social Care Council. In general, the remit of social work in the UK is being narrowed and specialised: there is a reduced opportunity for social workers to practice with adults and in the general provision of welfare, but their role in child protection and corporate parenting is being consolidated. Such trends are not evident in Sweden where there is less protection for social work as a distinct occupation (Blom et al., 
2006). This continues to be the case, despite several attempts to secure protection having been made by the social work association ${ }^{3}$.

By means of their scholarship, social work academics, and practitioners, have attempted to resist aspects of managerialism and neoliberalism that appear to jeopardise valued principles and practices associated with the welfare state, as well as the practice and 'profession' of social work (for example, Froggett, 2002; Harris 2003; Rogowski, 2007 and Rogowski 2010). Others have argued for a 'new professionalism' that combines technical competence with a practice that is 'more politically and socially engaged' and which has some 'radical spirit' (Lymbery, 2001: 381; see also Payne, 2006 and Adams et al., 2002).

Resistance to the changes in social work also occurred in the UK in 2009 when a rally was staged. Taking place in London and entitled Taking Back our Profession the rally was mounted by the British Association of Social Workers. This event was timed to coincide with the publication of the report of the Social Work Task Force (Social Work Task Force, 2009), which had been commissioned by the Secretaries of State for Health, and Children, Schools and Families. With fifteen recommendations for strengthening the status and practice of social work in the UK, this report might constitute a watershed. Two developments followed on from the work of the Social Work Task Group: firstly, the establishment of the Social Work Reform Board, which in 2010 published detailed proposals for change (Social Work Reform Board, 2010); and secondly, the UK government commissioned Professor Eileen Munro to report on child protection in England. Taking a systemic perspective, this extensive

\footnotetext{
${ }^{3}$ Personal communication with a former union chair for the social work association
} 
review suggests the way towards improvement (Munro 2011). Whilst not suggesting that there ever was a 'golden era' of social work, Munro challenges the managerialist developments that have occurred and recommends a retrieval of the 'professional' components that have become eroded.

\section{Summarizing Thoughts}

Exploring neo-liberalism and social work in two different countries involves many complexities. In addition to some different meanings of 'social work', each country is subject to different historical contexts. Despite the dominating status of the neoliberal discourse or ideology, it is but one influence in a range of competing influences. In consequence, we do not suggest that there is a simple, linear cause and effect relationship between neoliberalism and the changes in social work in Sweden and the UK. Nevertheless, it is suggested that the exploration of social work in the light of neoliberalism is worthwhile, because social work offers a symbolic comment on the different ways in which welfare is provided and certain social relationships are constructed and acted upon.

In Sweden a social democratic approach to policy and practice has been most significant through much of the post-war period. The UK has, by contrast, experienced a more consistently liberal orientation, something reflected in Esping-Anderson's (1990) characterization of welfare regimes in Sweden and the UK as social democratic and liberal respectively. These different welfare traditions and trajectories, and therefore different welfare architectures, appear to be moderating the progress and influence of neoliberalism: 
neoliberalism has made its appearance in both countries, but it became influential first in the UK - in the late 1970s, and slightly later in Sweden - in the early 1990s.

In Sweden, the tradition of solidarism (Hirst, 1998), though possibly dwindling now, may have mediated the progress of the neoliberal influence. In contrast, the history of liberalism in the UK might have encouraged its development. Despite such differences, both countries have witnessed a gradually increasing emphasis on citizenship, rights, and choice as well as personal responsibilities, for example, to live independently and be gainfully employed (Olofsson, 2009). Although employment has been a consistent plank of social policy in Sweden, more recently there have developed moral overtones and benefit entitlements have been altered. Within this ideological/discursive framework, marketization and the commodification of welfare services provide the opportunities for choice, but also the minimization of cost (in theory at least). Legislative change, audit, managerialism and performativity are measures by which political and policy directives are maintained. However, it is important to note that these are more evident in the UK than in Sweden. It is this context that is giving rise to the construction and reconstruction of social work.

Whilst there are differences in social work in Sweden and the UK, a similar role is performed in both countries, and there are some shared historical and theoretical foundations. For example, influenced by sociology, social workers in both countries in the 1960s and 1970s were motivated to some extent by a radical agenda which was concerned with social change as a means of preventing social problems (Wahlberg, 2001 and Evans and Harris, 2004). At the beginning of the twenty-first century however, social work practice in both countries has 
become both managerialist (Berg et al., 2008) and technicist (Ferguson, 2011 and Harlow, 2003).

However, today there remain some important contrasts between social work in Sweden and the UK. In the UK, social work is being narrowed in remit, yet consolidated by means of degree level qualification, the requirement for registration and a protected title. Despite this consolidation, the reconfiguration which involves managerialism, technicism and performativity, means social work in the UK has been described as marginalized and deprofessionalized: for example, the opportunity to use training, experience and independence of judgment to define and address social need has been compromised. Such criticism of the changes, which have been mounted by academics and practitioners, constitute a form of resistance. In contrast, resistance to change in social work is less evident in Sweden, where its remit has been retained though there has been no protection by means of accreditation and nomenclature. In examining the contestation of the neoliberal influences in social work, it appears to be taking sharper form in what might be seen as the country that provides its more favourable conditions - the UK. In Sweden resistance seems more muted, with solidarism (even though dwindling) providing surprisingly fertile soil for the incorporation of these developments. For those interested in contemporary organizations, we hope this exploration of the ways in which global forces might contribute to national developments, stimulates debate and provides the impetus for further reflection.

References 
Ackroyd S, Kirkpatrick I and Walker R (2007) Public management, reform in the UK and its consequences for professional organization: a comparative analysis, Public Administration 85(1): 11-26.

Adams R, Dominelli L and Payne M (2002) Concluding comment: past, present and future of social work. In: Adams R, Dominelli L and Payne M (eds) Social Work: Themes, Issues and Critical Debates (Second edition). Basingtoke: Palgrave, pp.

Åström K (2000) Förändringar och förskjutningar i välfärdens rättsliga reglering under 1990talet. In: SOU 2000:38 Välfärd, vård och omsorg. Stockholm: Socialdepartementet, pp..

Barnes D and Hugman R (2002) Portrait of social work. Journal of Interprofessional Care 16 (3): $277-288$.

Barnett C (2009) Publics and markets: what's wrong with neoliberalism? In: Smith S, Pain R, Marston R and Jones JP III (eds) The Sage Handbook of Social Geography. London: Sage, pp. 269-296.

Berg E (2003) Women's positioning in a bureaucratic environment - combining employment and mothering. In: Barry J, Dent M and O'Neal M (eds) Gender and the Public Sector. London: Routledge, pp.

Berg E (2008) Samverkan över organisationsgränser - några teoretiska reflektioner. In: Berg E (ed) Regionala samarbetsprojekt i Norrbottens län - Socialtjänsten, psykiatrin och primärvården. Luleå: Luleå Tekniska Universitet, pp. 13 - 25.

Berg E, Barry J and Chandler J (2008) New public management and social work in Sweden and England: challenges and opportunities for staff in predominantly female organizations. International Journal of Sociology and Social Policy 28 (3/4): 114-128.

Birch K and Mykhnenko V (2009) Varieties of neoliberalism? Restructuring in large industrially dependent regions across Western and Eastern Europe. Journal of Economic Geography 9 (3): 355-380.

Blom B, Morén S and Nygren L (eds) (2006) Kunskap i socialt arbete. Om villkor, processer och användning. Stockholm: Natur \& Kultur. 
Brand J (2009) The death of good practice? Professional Social Work October: 10-11.

Butler I and Pugh R (2004) The politics of social work research. In: Lovelock R, Lyons K and Powell J (eds) Reflecting on Social Work Discipline and Profession. Aldershot: Ashgate.

Carey M (2009) 'It's a bit like being a robot or working in a factory': Does Braverman help explain the experiences of state social workers in Britain since 1971? Organization 16 (4): 505-527.

Christenson T and Lægreid P (2007) Transcending New Public Management: The Transformation of Public Sector Reforms. Aldershot: Ashgate.

Clarke J (2004a) Dissolving the public realm? The logics and limits of neo-liberalism. Journal of Social Policy 33 (1): 27-48.

Clarke J (2004b) Changing Welfare Changing States: New directions in social policy. London: Sage.

Clarke J and Newman J (1993) Managing to survive: dilemmas of changing organizational forms in the public sector. In: Page R and Deakin N (eds) The Costs of Welfare. Aldershot: Avebury, pp.

Clarke J and Newman J (1997) The Managerial State. London: Sage.

Clarke J, Cochrane A and McLaughlin E (1994) Managing Social Policy. London: Sage.

Craig D and Cotterell G (2007) Periodising neoliberalism? Policy and Politics 35(3): 497514.

Dent M and Whitehead S (eds) (2002) Managing Professional Identities: Knowledge, Performativity and the 'New' Professional. London: Routledge. 
Department for Education and Skills (2005a) Common Core of Skills and Knowledge for the Children's Workforc. London: Stationary Office.

Department for Education and Skills (2005b) Common Assessment Framework for Children and Young People: Guide for Service Managers and Practitioners. London: Stationary Office

Department for Children, Schools and Families (2008) Piloting the Social Work Practice Model: A Prospectus. Nottingham: Department for Children, Schools and Families.

England, H. (1986) Social Work as Art: making Sense for Good Practice. London: Allen and Unwin.

Esping-Anderson G (1990) The Three Worlds of Welfare Capitalism. Cambridge: Polity Press.

Evans T and Harris J (2004) Street level bureaucracy, social work and the (exaggerated) death of discretion. British Journal of Social Work 43: 871-895.

Ferguson H (2011) Child Protection Practice. Basingstoke: Palgrave Macmillan.

Fisher M (2002) The Social Care Institute for Excellence: the role of a national institute in developing knowledge and practice in social care. Social Work and Social Sciences Review 10(2): 6-34.

Friedman M (1962) Capitalism and Freedom. Chicago: University of Chicago Press.

Froggett L (2002) Love, Hate and Welfare. Psychosocial Approaches to Policy and Practice. Bristol: Policy Press.

Fukuyama F (1989) The end of history? In: Ball T and Dagger R (eds) (1991) Ideals and Ideologies: A Reader. New York: Harper Collins, pp.. 
Garrett PM (2008) How to be modern: new labour's neoliberal modernity and the change for children programme. British Journal of Social Work 38(2): 270-289.

Garrett PM (2009) Transforming Children's Services: Social Work, Neoliberalism and the 'Modern' World. Buckingham: Open University Press.

General Social Care Council (2008) Protection of Title. available at: http://www.gscc.org.uk/The+Social+Care+Register/Protection+of+title/ (accessed 28 June 2008).

Harlow E (2003) New managerialism, Social Services Departments and social work practice today. Practice 15(2): 29-44.

Harlow E (2004) Why don't women want to be social workers anymore? New managerialism, postfeminism and the shortage of social workers in Social Services Departments in England and Wales. European Journal of Social Work 7(2): 167-179.

Harris J (1998) Scientific management, bureau-professionalism and new managerialism: the labour process of state social work. British Journal of Social Work 28(6): 839-862.

Harris J (2003) The Social Work Business. London: Routledge.

Harvey D (2005) A Brief History of Neoliberalism. Oxford: Oxford University Press.

Hayek FA von (1966) The principles of a liberal social order. In: Crespign AD and Cronin J (1980) (eds) Ideologies of Politics. Oxford: Oxford University Press, pp.55-75.

Hayek FA von (1944) The Road to Serfdom. London: George Routledge and Sons Ltd.

Hinnfors J (2006) Reinterpreting social democracy A history of stability in the British Labour Party and Swedish Social Democratic Party. Manchester University Press, Manchester. 
Hirst P (1998) Can the European welfare state survive globalization? Sweden, Denmark and the Netherlands in comparative perspective. Working Paper Series in European Studies 2 (1) London: Birkbeck College, University of London.

Holmberg I and Henning R (2003) Offentligt ledarskap : om förändring, förnyelse och nya ledarideal. Lund: Studentlitteratur.

James AL (2004) The McDonaldization of social work - or come back Florence Hollis, all is (or should be) forgiven. In: R. Lovelock, K. Lyons and J. Powell J (eds) Reflecting on Social Work - Discipline and Profession Aldershot: Ashgate, pp..

Jones C (2001) Voices from the front line: state social workers and New Labour. British Journal of Social Work 31: 547-562.

Jordon B with Jordon C (2000) Social Work and the Third Way. Tough Love as Social Policy. London: Sage.

Kasza GJ (2002) The illusion of welfare "regimes". Journal of Social Policy 31(2): 271-287.

Kelly A (1991) The "new" managerialism in the social services. In: Carter P, Jeffs T and Smith MK (eds) Social Work and Social Welfare Year Book 3. Buckingham: Sage, pp.

Larner (2000)

Larsson T (2002) Sweden. In: OECD Distributed Public Governance. Agencies, authorities and other public bodies. Paris: OECD.

Lawler J (2000) The rise of managerialism in social work. In: Harlow E. and Lawler J (eds) Management, Social Work and Change Aldershot: Ashgate, pp.33-55.

Lewis (2009) 
Leys C (2001) Market-Driven Politics: Liberal Democracy and the Public Interest. London: Verso.

Local Authority Workforce Intelligence Group, (2006) Adult, Children and Young People Local Authority Social Care Workforce Survey 2005. London: Local Government Association, Available at: www.lga.gov.uk/Documents/Briefing/Our_Work/Projects/workforcesurvey.pdf, (accessed $18 / 11 / 06)$

Lymbery M (2001) Social work at the crossroads. British Journal of Social Work, 31: 369384.

McLaughlin H (2009) What's in a name: "client", "patient", "consumer", "expert by experience", "service user" - what's next? British Journal of Social Work 39(6): 1101-1117.

Marr A (2007) A History of Modern Britain. London: Pan Macmillan.

Meeuwisse A, Sunesson S and Swärd H (2006) Socialt Arbete En grundbok, Bokförlaget Natur och Kultur. Stockholm: Natur och Kultur..

Munro E (2011) The Munro Review of Child Protection: Final Report. A Child Centred System. Norwich: The Stationary Office.

The National Board of Health and Welfare, SOSFS 2006:14 (S).

Newman J (2001) Modernising Governance. London: Sage.

Olofsson J (2009) Socialpolitik, varför, hur och till vilken nytta? SNS Förlag Stockholm.

Oscarsson H (2000) "Partiernas sympatikapital!" I Det nya samhället. Som-rapport 24,Red. Sőren Holmberg and Lennart Weibull, 279-286. Gőteborgs Universitet:Som-institutet. 
Payne M (2005) Modern Social Work Theory. Basingstoke: Macmillan Palgrave.

Payne M (2006) What is Professional Social Work? (Revised second edition). Bristol: Policy Press.

Pollitt C and Bouckaert G (2004) Public Management Reform: A Comparative Analysis. (Second edition) Oxford: Oxford University Press.

Postle K (2001) The social work side is disappearing. I guess it started with us being called care managers. Practice 13(1): 13-26.

Powell F (2001) The Politics of Social Work London: Sage.

Rogowski S (2007) Our eroding profession. Professional Social Work March: 14-15.

Rogowski S (2010) Social Work. The Rise and Fall of a Profession. Bristol: The Policy Press.

Rosen A (2003) Evidence-based social work practice: challenges and promise. Social Work Research 27(4):197-208.

Sackett DL, Richardson WS, Rosenberg W and Hayes RB (1997) Evidence-Based Medicine: How to Practice and Teach EBP. New York: Chirchill Livingstone.

Sellick C (2007) Towards a mixed economy of foster care provision. Social Work and Social Sciences Review 13(1) 25-40.

Siddall A (2000) From Beveridge to Best Value: transitions in welfare provision. In: Harlow E and Lawler J (eds) Management, Social Work and Change Aldershot: Ashgate, pp.19-31.

Social Work Task Force (2009) Building a Safe, Confident Future. The Final Report of the Social Work Task Force: November 2009 
Social Work Reform Board (2010) Building a Safe and Confident Future: One Year On. Detailed Proposals from the Social Work Reform Board. London: Department for Education.

SOU (2008:18) Evidensbaserad praktik inom socialtjänsten- till nytta för brukaren. Stockholm: Socialdepartementet.

Svensson K Johnsson E and Laanemets L (2008) Handlingsutrymme Utmaningar i socialt arbete. Stockholm: Natur \& Kultur.

Wahlberg S (2001) Samhällsarbete - strategier för ett radikalt och humanistiskt socialt arbete. Stockholm: Norstedts Juridik.

Wilding P (1986) Introduction. In: Wilding P (1986) (ed) In Defence of the Welfare State (12). Manchester: Manchester University Press, pp.. 